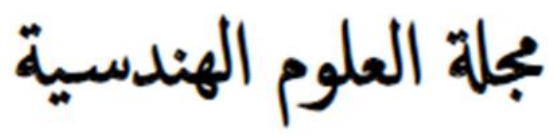

\title{
Effects of Limestone Powder on Self-compacting Concrete Properties
}

\author{
Yousif Hummaida Ahmed ${ }^{1, *}$ and Khalid Salah Eldin Babikir ${ }^{1}$ \\ 1 Civil Engineering Department, Faculty of Engineering, University of Khartoum, Khartoum, Sudan, P. O. Box 321. \\ * Corresponding author: Yousif Hummaida Ahmed (e-mail: Y.hummaida@uofk.edu).
}

Article history: Received 11 March 2020, Received in revised form 4 November 2020, Accepted 11 November 2020

\begin{abstract}
Powder type of self-compacting concrete (SCC) needs high cement content to achieve self-compactibility, this will be undesirable in tropical climate of Sudan due to implication of high hydration heat. This paper investigates reducing cement content up to $340 \mathrm{Kg} / \mathrm{m}^{3}$ by blending limestone powder (LSP) up to $15 \%$ as replacement of cement weight. Therefore, fifteen mixes having maximum powder content $(\mathrm{P})$ of $400 \mathrm{Kg} / \mathrm{m}^{3}$ have been carried out with four water/powder ratios $(\mathrm{W} / \mathrm{P})(0.35,0.4$, 0.43 and 0.45 ). Fresh properties and compressive strength of SCC were measured. Results show most of the mixes have achieved self-compactibility in the fresh stages. However, the compressive strength of the mixes has been reduced with increased level of LSP replacing cement. This reduction in strength is caused by dilution effect of adds LSP.
\end{abstract}

Keywords: Self-compacting concrete, Limestone powder, Slump flow, Visual stability index, Dilution effects.

\section{INTRODUCTION}

Self-compacting concrete (SCC) is the most common new concrete technology in the world. It has been designed to minimize noise and health risk of vibration and get smooth surface finishing concrete. The SCC has also known as self-consolidating concrete, self-leveling concrete and self-placing concrete. Normally, it is concrete made with the same materials of conventional concrete, but in some cases viscosity modifying admixture (VMA) are behaved to succeed the homogeneity of mixes and control powder content. The main properties to clarify workability of SCC are flow-ability, passing-ability and stability during the flow (dynamic stability) and after a few minutes of flow (static stability). In general, the ratio of cement paste/mortar matrix and aggregate volume are preferred to achieve self-compactibility and required compressive strength [1]-[4]. Fresh properties of the SCC needs special quality control that due to high deformability of SCC mixes and their sensitivity to changes in ingredient properties [5]. Moreover, numerical simulations of SCC have been used to assess its properties [6].

Koura et al. [4] reported that an increasing in the solid phase (aggregates content) which lead to decreasing the liquid phase (cement paste content), that could obtain high internal friction that increase the hazard of blockage and reduce the flow-ability. However, decreasing in powder content affects negatively in mechanical properties of SCC by increasing the segregation. To reduce cement content and improve workability of SCC supplementary cementitious materials (SCMs) and filler materials (FMs) have been used, such as fly ash, silica fume, metakaolin, limestone powder, as well as viscosity modifying admixtures (VMA).

Limestone powder (LSP) is the most popular materials utilizing to SCC mixes, and it has been widely performed in concrete due to its wide availability and low cost [5], [7]-[15]. It has been easy seen that the grinding of LSP needs lower energy compared to clinker as the same particle size [10]. Therefore, numerous national standard 
have recommended to utilize LSP in concrete applications such as European standard (EN 197-1), American standard (ASTM C595), Canadian standard (CSA A3001-10) and Chinese standard (JC/T 600-2010) [11], [12], [16].

The action mechanism of LSP generally influences by its particle size and amount. However, it has been reported that, the effects of LSP on the properties of concrete may be summarized as physical effect (filler, nucleation and dilution) and chemical effect. Consequently, if very fine particle size of LSP is utilized comparable to cement particle, combination of LSP could fill the voids of concrete and improve the packing density. It has been concluded that, the nucleation "defined as the first formation of a new phase that have ability to grow into larger sized nucleus within the system" effect of LSP has been observed once the particle size of LSP is equal to/or finer than cement particle is consumed or increase an amount of LSP. Moreover, increasing LSP amount will increase the nucleation effect and more hydration products could be noticed. In fact, LSP does not have the same chemical reactivity as cementitious or pozzolanic materials. However, at the same W/P replacement of cement by using coarse LSP decreases the cement content in the system and lead to increase water to cement ratio, which is recognized as dilution effect. It has been observed that, calcium carbonate (especially Nano-limestone powder) react with aluminate phase and gives new components known as calcium mono-carboaluminate and calcium hemi-carboaluminate instead of calcium mono-sulphoaluminate and that could stabilize the ettringite. Otherwise, rich aluminate phase could provide from $\mathrm{C}_{3} \mathrm{~A}$ and $\mathrm{C}_{4} \mathrm{AF}$ in cement as well as SCMs [7], [10]-[12], [16]-[27].

Particle size, particle shape and quantity of LSP have great influence on the fresh properties and workability of concrete [11]. Hafez et al. [28] concluded that, flow-ability, segregation and bleeding resistance affect by filler types. It has been informed that, utilizing LSP has great effect on the SCC fresh properties [9], [29]-[35]. Walid et al. [36] reported that, using LSP as cement replacement has a negative effect on passing-ability of SCC. Reference [37] reported that, LSP increases the yield stress and plastic viscosity of the pastes and decreases the fluidity of mortars.

Mechanical properties of concrete will increase when fine LSP or small quantity to replace cement content is used caused by filler, nucleation and chemical effects. When coarse LSP or large quantity to replace cement content is used, it will reduce the mechanical properties of concrete caused by dilution effect. Effects of LSP on the compressive strength of cement paste have been experimented. Whatever, with decrease in particle size of LSP the physical effect of LSP on compressive strength could decrease, however the chemical effect will increase. Therefore, LSP improves the rate of hydration and that could increase the compressive strength at early ages [38]. Hence, LSP has a positive effect on the compressive strength once the quantity of LSP increases [5], [9], [11], [16], [18], [20], [30], [37], [39], [40]. However, a reduction on compressive strength due to LSP has been noticed [19], [25], [34]-[36], [41], [42]. Mahmoud et al. [43] stated that, $50-60 \mathrm{MPa}$ compressive strength of SCC could be achieved using $450 \mathrm{Kg} / \mathrm{m}^{3}$ powder content with 33\% cement replacement by LSP.

Integrating suitable fine LSP or small amount increases the nucleation effect and that accelerates the hydration of $C_{3} S$, increases the hydration degree. The chemical effect of LSP forms carboaluminate and increases the hydration heat of cement at early ages, but a little effect at long-term. Moreover, filler effect of LSP has slight hydration effect rather than dilution effect which decreases the hydration degree [11], [12], [14], [16], [17], [25], [42], [44].

It has been reported that, to reduce the porosity of concrete and improve the durability, LSP shall be used less than $15 \%$. However, several researches have investigated the deterioration of LSP on concrete under sodium and magnesium sulfate attack. It has been concluded that the specimens of concrete acutely damage during the time caused by the expansion and loss on strength. It has been stated that the type of sulfate solution have grate impact on the concrete deterioration [19], [45]-[48].

Referring to previous study, there are five categories of SCC mix design method recognized as empirical design method, compressive strength method, closed aggregate packing method, 
rheology of paste method and statistical method [49].

In this study an empirical design method has been used. The overarching aim of this study is to investigate the effects of LSP on the fresh and compressive strength of SCC. In this experimental study ordinary Portland cement (OPC) has been reduced by utilizing LSP up to $15 \%$ by weight, to decrease the risk of cracking caused by cement hydration and shrinkage. This paper consists of this section, experimental work, result and discussions, conclusions and recommendations.

\section{EXPERIMENTAL WORK}

\section{A. Materials}

The SCC mixtures in this study are carried out containing the following materials, ordinary Portland cement (OPC) CEM I $42.5 \mathrm{~N}$, limestone powder (LSP) from River Nile state/Sudan, natural fine aggregate (FA), uncrushed coarse aggregate (CA), tap water (W) and high range water reducing admixture (super-plasticizer (SP)) (type (F)) with the solid content $35 \%$ and specific gravity 1.15 @ $25{ }^{\circ} \mathrm{C}$. The chemical composition and physical properties of OPC and LSP are listed in Table (1) and Table (2), respectively. The particle size distributions and other physical properties of raw materials are showed in Fig (1) and Table (3), respectively.

\section{B. Mixes designed in this work}

Until now, there is no standard method or code for SCC mix design. However, according to ACI 237R-07 [1], European guidelines for SCC [2] and authors' previous study [5] fifteen SCC mixes have been carried out.

\section{Test methods}

In this experimental work the following tests were used, slump flow test, $T_{500}$, visual stability index and sieve segregation test to measure the fresh properties of SCC mixes. The procedure of using these tests are reported in ACI 237R-07 [1] and BS EN 206-9:2010. Moreover, compressive strength were assessed by using $\left(150^{*} 150^{*} 150\right)$ $\mathrm{mm}^{3}$ at deferent ages (3, 7 and 28$)$ days.

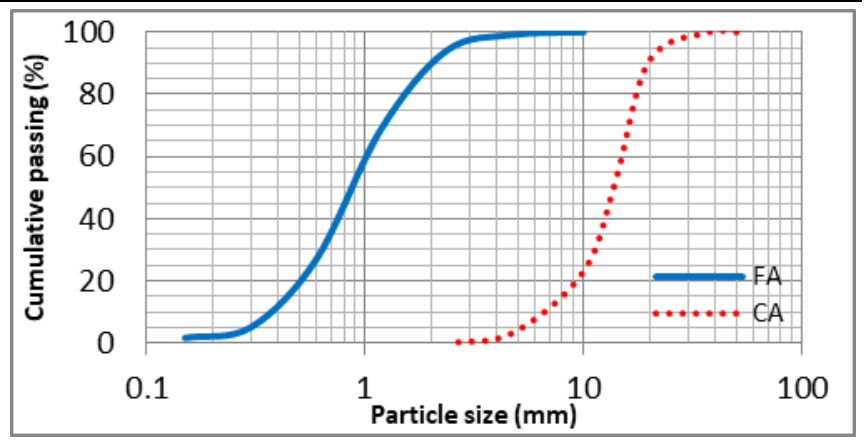

Fig. 1. Particle size distribution of aggregates.

\section{Mixture proportions}

Fifteen SCC mixes were calculated with maximum powder content $400 \mathrm{Kg} / \mathrm{m} 3$. These SCC mixes having uniform mortar volume. Besides that, $2 \%$ dosage of super-plasticizer was used. Allover SCC mixes are divided in four categories depending on its $\mathrm{W} / \mathrm{P}$, in four percentages of cement replacement level $(0 \%, 5 \%, 10 \%$ and $15 \%)$ by blending LSP. Table (4) shows the SCC mix proportions in this experimental work.

\section{E. Mixing procedure}

In this experimental work forced pan mixer with 22 revolutions per minute (rpm) was used to obtain the SCC mixes. All mixes have been mixed at laboratory environment (25-35) ${ }^{\circ} \mathrm{C}$. Overall mixing has taken 12 minutes; it began by dry mixing of fine aggregate with powder to improve the fresh and mechanical properties by filling the voids of sand. Fig (2) shows the procedure and time line of each mixing.

TABLE 1: CHEMICAL COMPOSITION OF OPC AND LSP

\begin{tabular}{lllllllll}
\hline \hline & $\mathrm{CaO}$ & $\mathrm{MgO}_{\mathrm{O}}$ & $\mathrm{Na}_{2} \mathrm{O}$ & $\mathrm{K}_{2} \mathrm{O}$ & $\mathrm{Fe}_{2} \mathrm{O}_{2}$ & $\mathrm{SiO}_{2}$ & $\mathrm{Al}_{2} \mathrm{O}_{2}$ & LOI \\
\hline OPC & 66.33 & 2.47 & 1.56 & 0.75 & 3.39 & 18.29 & 3.45 & 2.21 \\
LSP & 43.11 & 1.50 & 1.24 & 0.23 & 1.00 & 1.33 & - & 42.36 \\
\hline
\end{tabular}

\begin{tabular}{ccc}
\multicolumn{2}{c}{ TABLE 2: PHYSICAL PROPERTIES OF OPC AND LSP } \\
\hline \hline Surface area $\left(\mathrm{cm}^{2} / \mathrm{g}\right)$ & OPC & LSP \\
\hline Specific gravity & 3680 & 1854 \\
Average particle size $(\mu \mathrm{m})$ & 3.1 & 2.6 \\
\hline TABLE 3: PHYSICAL PROPERTIES OF RAW MATERIALS \\
\hline \hline Specific gravity & 30 & 75 \\
\hline CA & FA \\
Rodded bulk density $\left(\mathrm{Kg} / \mathrm{m}^{3}\right)$ & 2.65 & 2.64 \\
Loose bulk density $\left(\mathrm{Kg} / \mathrm{m}^{3}\right)$ & 1660 & 1750 \\
Fineness modulus & 1525 & 1700 \\
Crushing value $(\%)$ & 3.3 & 3 \\
Water absorption $(\%)$ & 22 & - \\
Voids content $(\%)$ & 0.717 & 0.28 \\
Nominal particle size $(\mathrm{mm})$ & 43 & 35.1 \\
\hline \hline
\end{tabular}




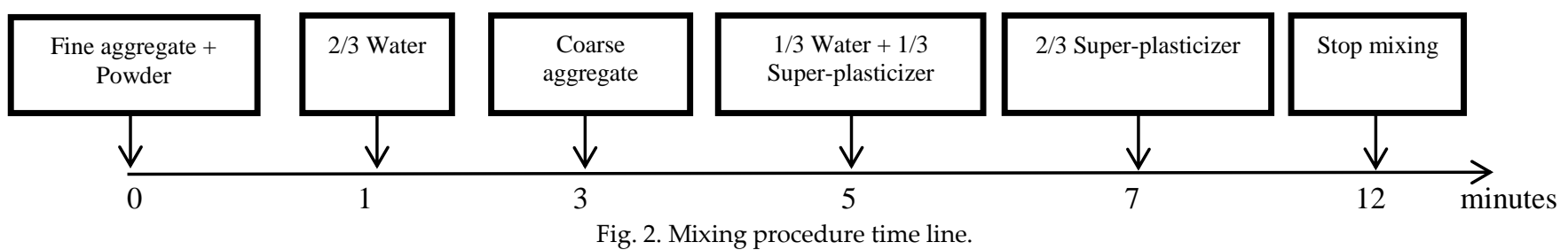

TABLE 4: MIX PROPORTIONS ON THIS EXPERIMENTAL WORK

\begin{tabular}{|c|c|c|c|c|c|c|c|c|c|c|c|c|c|}
\hline & $\begin{array}{c}\mathrm{LSP} / \mathrm{P} \\
(\%)\end{array}$ & $\begin{array}{l}\text { OPC } \\
(\mathrm{Kg})\end{array}$ & $\begin{array}{l}\text { LSP } \\
(\mathrm{Kg})\end{array}$ & $\begin{array}{c}\mathrm{P} \\
(\mathrm{Kg})\end{array}$ & $\begin{array}{l}\mathrm{CA} \\
(\mathrm{Kg})\end{array}$ & $\begin{array}{l}\text { FA } \\
(\mathrm{Kg})\end{array}$ & $\begin{array}{c}\mathrm{W} \\
(\mathrm{Kg})\end{array}$ & $\begin{array}{c}\mathrm{SP} \\
(\mathrm{Kg})\end{array}$ & $\begin{array}{c}\mathrm{OPC} / \mathrm{P} \\
(\%)\end{array}$ & $\mathrm{W} / \mathrm{P}$ & W/OPC & $\begin{array}{c}\text { FA/Agg. } \\
(\%)\end{array}$ & $\begin{array}{c}\text { Paste } \\
(\%)\end{array}$ \\
\hline SCC 1-REF & 0 & 400 & 0 & 400 & 830 & 1032 & 140 & 8 & 1 & 0.35 & 0.35 & 55.42 & 29.60 \\
\hline SCC 2-REF & 0 & 400 & 0 & 400 & 750 & 1059 & 160 & 11 & 1 & 0.4 & 0.4 & 58.5 & 31.60 \\
\hline SCC 3-REF & 0 & 400 & 0 & 400 & 930 & 879 & 160 & 8 & 1 & 0.4 & 0.4 & 48.6 & 31.60 \\
\hline SCC 4-REF & 0 & 400 & 0 & 400 & 830 & 979 & 160 & 8 & 1 & 0.4 & 0.4 & 54.12 & 31.60 \\
\hline SCC 5-5\%LSP & 5 & 380 & 20 & 400 & 830 & 976 & 160 & 8 & 0.95 & 0.4 & 0.421 & 54.03 & 31.72 \\
\hline SCC $6-10 \%$ LSP & 10 & 360 & 40 & 400 & 830 & 972 & 160 & 8 & 0.9 & 0.4 & 0.45 & 53.95 & 31.85 \\
\hline SCC 7-15\%LSP & 15 & 340 & 60 & 400 & 830 & 970 & 160 & 8 & 0.85 & 0.4 & 0.471 & 53.87 & 31.97 \\
\hline SCC 8-REF & 0 & 400 & 0 & 400 & 830 & 947 & 172 & 8 & 1 & 0.43 & 0.43 & 53.29 & 32.8 \\
\hline SCC 9-5\%LSP & 5 & 380 & 20 & 400 & 830 & 944 & 172 & 8 & 0.95 & 0.43 & 0.453 & 53.21 & 32.9 \\
\hline SCC $10-10 \%$ LSP & 10 & 360 & 40 & 400 & 830 & 941 & 172 & 8 & 0.9 & 0.43 & 0.478 & 53.13 & 33.05 \\
\hline SCC 11-15\%LSP & 15 & 340 & 60 & 400 & 830 & 937 & 172 & 8 & 0.85 & 0.43 & 0.506 & 53.03 & 33.17 \\
\hline SCC 12-REF & 0 & 400 & 0 & 400 & 730 & 1026 & 180 & 8 & 1 & 0.45 & 0.45 & 58.4 & 33.60 \\
\hline SCC 13-REF & 0 & 400 & 0 & 400 & 830 & 926 & 180 & 8 & 1 & 0.45 & 0.45 & 52.74 & 33.60 \\
\hline SCC $14-10 \%$ LSP & 10 & 360 & 40 & 400 & 830 & 920 & 180 & 8 & 0.9 & 0.45 & 0.5 & 52.56 & 33.85 \\
\hline SCC $15-15 \%$ LSP & 15 & 340 & 60 & 400 & 830 & 916 & 180 & 8 & 0.85 & 0.45 & 0.53 & 52.47 & 33.97 \\
\hline
\end{tabular}

\section{RESULTS AND DISCUSSION}

\section{A. Slump flow and $T_{500}$}

Slump flow test is used to assess the flow-ability of SCC mixes by measuring the diameter of flowing concrete. Acceptable slump flow diameters are limited as $550-800 \mathrm{~mm}$. Overall SCC mixes were achieved a proper flow-ability. Therefore, slump flow increases with increase the dosage of LSP. This could be due to decreased water demand from lower of surface area of LSP particle size compare to OPC particle. Moreover, with increase the paste volume and water content increasing in slump flow diameter have been observed. Fig (3-4) presents effects of LSP percentage, water content and paste volume on the flow-ability of SCC mixes. It can be clearly seen that, quantity of LSP is important parameter to assess flow-ability of SCC.

Table (5) is listed the values of $T_{500}$ which is controlled the viscosity of SCC mixes. Therefore, it has been noticed that, as increase in flow time of slump flow test indicates that high viscosity. It could be easily seen that, LSP affects the viscosity of SCC. That may relate to particle shape and cohesiveness of LSP compare to OPC particle.

\section{B. Visual stability index}

According to ACI 237R-07 visual stability index (VSI) is indicated the dynamic stability and bleeding resistance of SCC by using slump flow test. It has been divided as high stable (0), stable (1), unstable (2) and high unstable (3). Table (5) is showed that, there is no enough evidences to corroborate that, LSP has a positive effect on dynamic stability and bleeding resistance of SCC. This could be attributed to the dilution effect of LSP, as the LSP is coarser than the OPC.

\section{Sieve segregation}

Sieve segregation test is used to measure the static stability of SCC mixes. These values are plotted in Table (5). It can be clearly seen that, the stability of SCC mixes influence by quantity of LSP. However, all most of SCC mixes have achieved the limitation of stability.

\section{Compressive strength}

In this study the compressive strength of SCC mixes has been measured at 3, 7 and 28 days by using $150^{*} 150^{*} 150 \mathrm{~mm}^{3}$. The results of SCC compressive strength tests are presented in Fig (5, 6 and 7). It is obviously seen that, an increase in LSP decrease the cement content and increase in 
water to cement ratio. This could reduce the compressive strength due to dilution effect (Fig 7). However, increasing the compressive strength may be due to filler effect, nucleation effect or could be due to produce of new components.
Otherwise, it would be caused by all the last mechanisms. Fig (6) is showed effect of LSP in the same water to cement ratio on compressive strength.

TABLE 5: FRESH PROPERTIES OF SCC MIXES

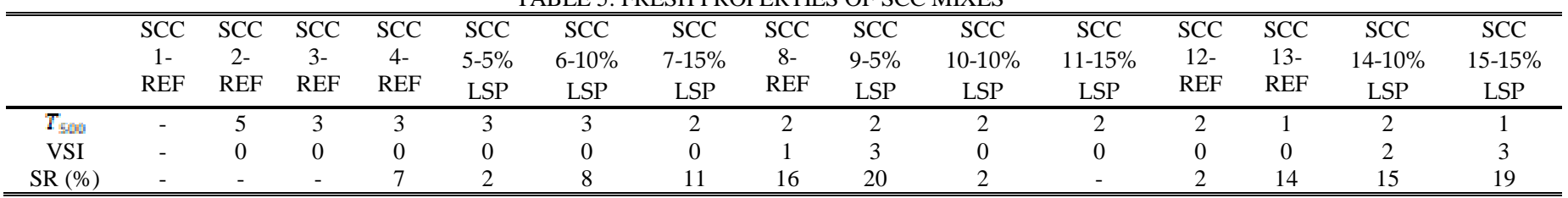

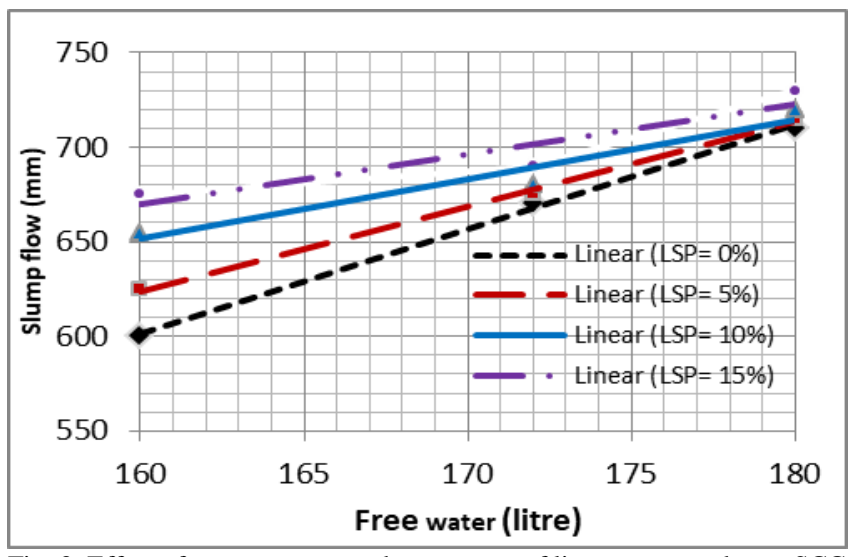

Fig. 3. Effect of water content and percentage of limestone powder on SCC Flow-ability measured by Slump Flow Test.

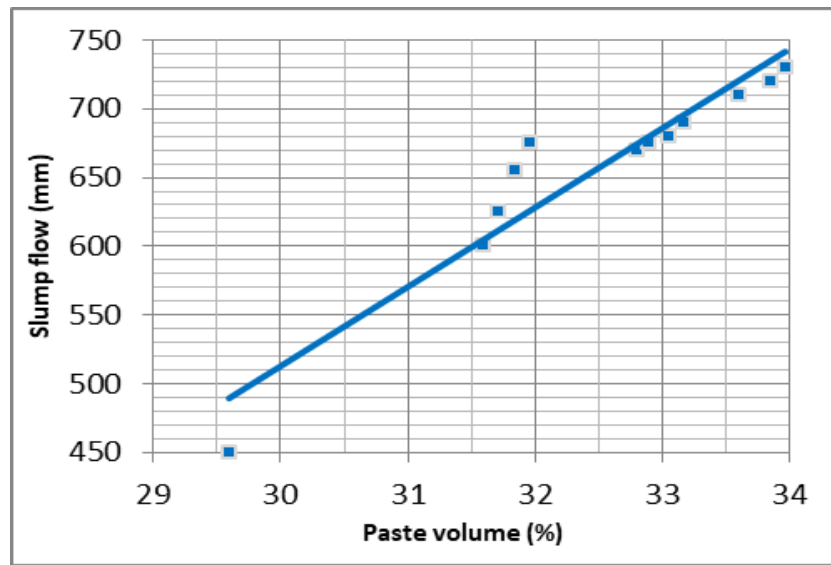

Fig. 4. Effect of paste volume on SCC Flow-ability measured by Slump Flow Test.

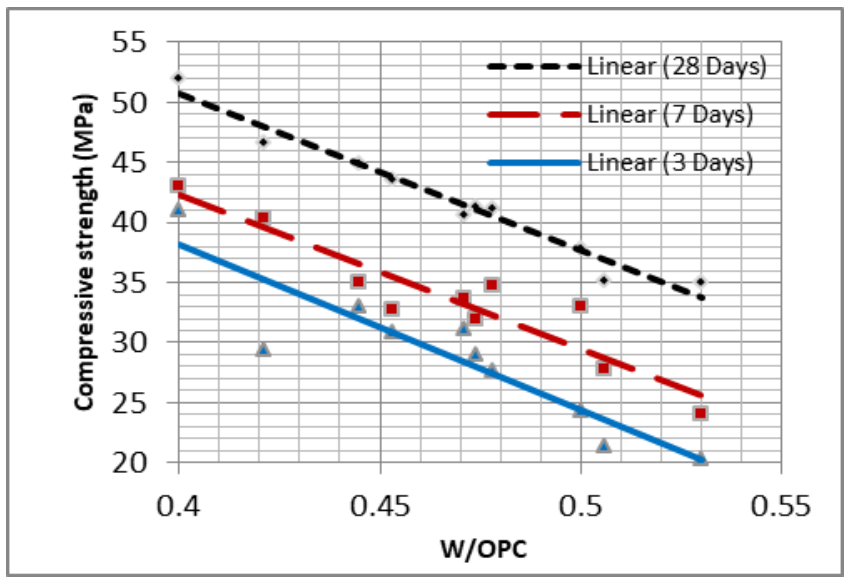

Fig. 5. Effect of blended cement limestone powder W/OPC on compressive strength

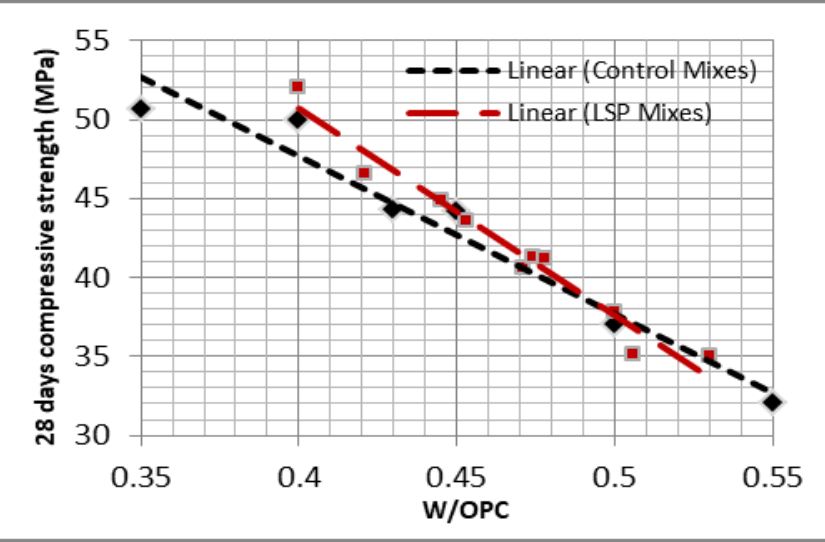

Fig. 6. Effect of limestone powder on compressive strength.

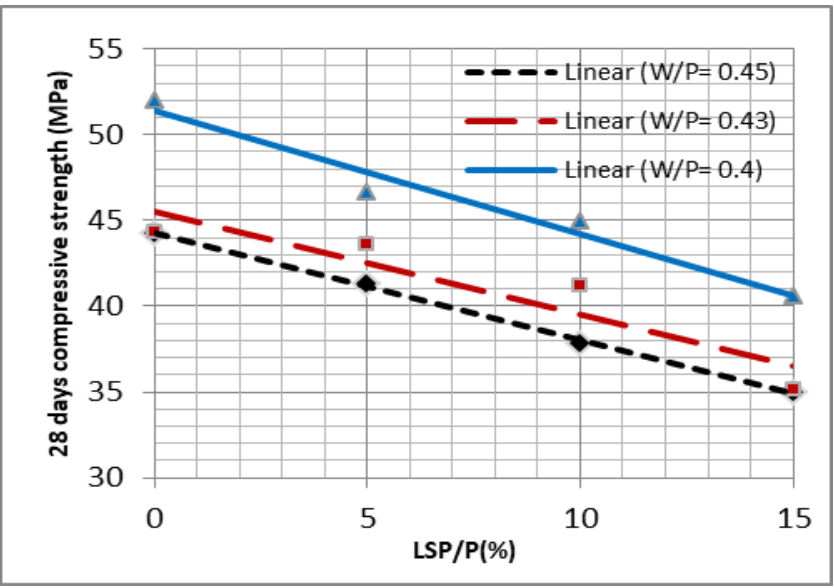

Fig. 7. Dilution effect of limestone powder and W/P on compressive strength.

\section{CONCLUSIONS}

It could be easily achieved self-compactibility with LSP as cement replacement materials.

Utilizing LSP coarser than cement particle has influence on the viscosity of SCC.

From previous studies and this experimental work the quantity of LSP is important property which affects the SCC properties.

In higher free water content, the effect of LSP in the slump flow is less than lower water.

Liquid phase (paste volume) has affected the slump flow diameter. It could be easily achieved 
(35-50) MPa compressive strength with cement replacement up to $15 \%$ by LSP.

In lower water to cement ratios, LSP effecting is more effective in compressive strength.

Dilution effect on compressive strength is observed with increasing the amount of LSP.

\section{RECOMMENDATIONS}

To investigate the effect of forced pan mixer on the SCC properties, overall samples of testing should be gotten at the same time as much as possible.

To neglect the dilution effect, grinding of limestone particle size (similar or lesser than OPC) should be taken into account.

Supplementary cementitious materials should be added with limestone powder to stabilize the ettringite and setting time.

Viscosity modifying admixture should be investigated such as Arabic gum.

Durability and long-term properties should be investigated.

\section{ACKNOWLEDGMENT}

The authors gratefully would like to acknowledgment financial support from Ouf-Brothers for construction (OBC). Also wish to thank the assistance given by Dr. Mahgoub Osman Mahgoub and the staff of Concrete and Materials Laboratory in Civil Engineering Department Faculty of Engineering, University of Khartoum.

\section{REFERENCES}

[1] ACI Technical committee 237 Self-consolidating concrete American concrete Institute, First printing, April 2007, p. 1-30.

[2] BIBM, CEMBUREAU, ERMCO, EFCA, EFNARC. The European Guidelines for Self-Compacting Concrete - specification, production and use, Available from: www.efca.info or www. efnarc.org, 2005 (May), p. 1-63.

[3] J. A. Daczko, Self-Consolidating Concrete. Spon Press, 2012.

[4] B. O. Koura, M. Hosseinpoor, A. Yahia, E. Kadri, and A. Kaci, "A new proportioning approach of low and normal binder self-consolidating concrete based on the characteristics of fine mortar and granular skeleton," Constr. Build. Mater., vol. 239, p. 117892, 2020, doi: 10.1016/j.conbuildmat.2019.117892.

[5] Y. H. Ahmed, K. Salah, and E. Babikir, "Proportioning self compacting concrete in hot weather of Sudan utilizing limestone powder," in 2nd conference on civil engineering-Sudan, 2018, pp. 140-146.

[6] H. Tran, J. Li, and Y. X. Zhang, "Numerical simulation of self-consolidating engineered cementitious composite flow with the V-funnel and U-box," Constr. Build. Mater., vol. 236, p. 117467, 2020, doi: 10.1016/j.conbuildmat.2019.117467.

[7] X. Wang, "Analysis of hydration and strength optimization of cement-fly ash-limestone ternary blended concrete," Constr.
Build. Mater., vol. 166, pp. 130-140, 2018, doi: 10.1016/j.conbuildmat.2018.01.058.

[8] P. L. Domone, "A review of the hardened mechanical properties of self-compacting concrete," Cem. Concr. Compos., vol. 29, pp. 1-12, 2007, doi: 10.1016/j.cemconcomp.2006.07.010.

[9] G. Sua-iam, P. Sokrai, and N. Makul, "Novel ternary blends of Type 1 Portland cement, residual rice husk ash, and limestone powder to improve the properties of self-compacting concrete," Constr. Build. Mater., vol. 125, pp. 1028-1034, 2016, doi: 10.1016/j.conbuildmat.2016.09.002.

[10] Hawkins P, Tennis P, Detwiler R. The Use of Limestone in Portland Cement: A State-of-the-Art Review. Portland cement associtation 2003.

[11] D. Wang, C. Shi, N. Farzadnia, Z. Shi, and H. Jia, "A review on effects of limestone powder on the properties of concrete," Constr. Build. Mater., vol. 192, pp. 153-166, 2018, doi: 10.1016/j.conbuildmat.2018.10.119.

[12] D. Wang, C. Shi, N. Farzadnia, Z. Shi, H. Jia, and Z. Ou, "A review on use of limestone powder in cement-based materials : Mechanism, hydration and microstructures," Constr. Build. Mater., vol. 181, pp. 659-672, 2018, doi: 10.1016/j.conbuildmat.2018.06.075.

[13] S. Bakhtiyari, A. Allahverdi, M. Rais-Ghasemi, A. A. Ramezanianpour, T. Parhizkar, and B. A. Zarrabi, "Mix design, compressive strength and resistance to elevated temperature $\left(500^{\circ} \mathrm{C}\right)$ of self-compacting concretes containing limestone and quartz fillers," Int. J. Civ. Eng., vol. 9, no. 3, pp. 215-222, 2011.

[14] A. Bourchy, L. Barnes-davin, L. Bessette, and J. M. Torrenti, "Effect of Cement Composition on Fresh State and Heat of Hydration of Portland Cement with Limestone and Slag," ACI Mater. J., vol. 117, no. January, pp. 153-166, 2020, doi: 10.14359/51719079.

[15] S. Ahmad, S. K. Adekunle, M. Maslehuddin, and A. K. Azad, "Properties of self-consolidating concrete made utilizing alternative mineral fillers," Constr. Build. Mater., vol. 68, pp. 268-276, 2014, doi: 10.1016/j.conbuildmat.2014.06.096.

[16] D. Wang et al., "A quantitative study on physical and chemical effects of limestone powder on properties of cement pastes A quantitative study on physical and chemical effects of limestone powder on properties of cement pastes," Constr. Build. Mater., vol. 204, no. April, pp. 58-69, 2019, doi: 10.1016/j.conbuildmat.2019.01.154.

[17] S. Kim, K. Yang, and G. Moon, "Hydration Characteristics of Low-Heat Cement Substituted by Fly Ash and Limestone Powder," Materials (Basel)., vol. 8, pp. 5847-5861, 2015, doi 10.3390/ma8095277.

[18] K. De Weerdt, M. Ben Haha, G. Le Saout, K. O. Kjellsen, H. Justnes, and B. Lothenbach, "Hydration mechanisms of ternary Portland cements containing limestone powder and fly ash," Cem. Concr. Res., vol. 41, no. 3, pp. 279-291, 2011, doi: 10.1016/j.cemconres.2010.11.014.

[19] M. Zajac, A. Rossberg, G. Le, and B. Lothenbach, "Influence of limestone and anhydrite on the hydration of Portland cements," Cem. Concr. Compos., vol. 46, pp. 99-108, 2014, doi: 10.1016/j.cemconcomp.2013.11.007.

[20] P. P. Li, H. J. H. Brouwers, W. Chen, and Q. Yu, “Optimization and characterization of high-volume limestone powder in sustainable ultra-high performance concrete," Constr. Build. Mater., vol. 242, p. 118112, 2020.

[21] A. Duran-herrera, J. De-león-esquivel, D. P. Bentz, and P. Valdez-tamez, "Self-compacting concretes using fly ash and fine limestone powder: Shrinkage and surface electrical resistivity of equivalent mortars," Constr. Build. Mater., vol. 199, pp. 50-62, 2019, doi: 10.1016/j.conbuildmat.2018.11.191.

[22] K. De Weerdt, K. O. Kjellsen, E. Sellevold, and H. Justnes, "Synergy between fly ash and limestone powder in ternary cements," Cem. Concr. Compos., vol. 33, no. 1, pp. 30-38, 2011, doi: 10.1016/j.cemconcomp.2010.09.006. 
[23] Y. Jeong and J. M. , Craig W. Hargis , Sungchul Chun, "Effect of Calcium Carbonate Fineness on Calcium Sulfoaluminate-Belite Cement," Materials (Basel)., vol. 10, p. 900, 2017, doi: 10.3390/ma10080900.

[24] C. Li, L. Jiang, and S. Li, "Effect of limestone powder addition on threshold chloride concentration for steel corrosion in reinforced concrete," Cem. Concr. Res., vol. 131, p. 106018, 2020.

[25] K. Celik, R. Hay, C. W. Hargis, and J. Moon, "Effect of volcanic ash pozzolan or limestone replacement on hydration of Portland cement," Constr. Build. Mater., vol. 197, pp. 803-812, 2019, doi: 10.1016/j.conbuildmat.2018.11.193.

[26] J. Ma, Z. Yu, C. Ni, H. Shi, and X. Shen, "Effects of limestone powder on the hydration and microstructure development of calcium sulphoaluminate cement under long-term curing," Constr. Build. Mater., vol. 199, pp. 688-695, 2019, doi: 10.1016/j.conbuildmat.2018.12.054.

[27] P. Thongsanitgarn, W. Wongkeo, A. Chaipanich, and C. Sun, "Heat of hydration of Portland high-calcium fly ash cement incorporating limestone powder: Effect of limestone particle size," Constr. Build. Mater., vol. 66, pp. 410-417, 2014, doi: 10.1016/j.conbuildmat.2014.05.060.

[28] H. E. Elyamany, A. Elmoaty, and M. Basma, "Effect of filler types on physical, mechanical and microstructure of self compacting concrete and Flow-able concrete," Alexandria Eng. J., vol. 53, pp. 295-307, 2014.

[29] S. Demirhan, K. Turk, and K. Ulugerger, "Fresh and hardened properties of self consolidating Portland limestone cement mortars: Effect of high volume limestone powder replaced by cement," Constr. Build. Mater., vol. 196, pp. 115-125, 2019, doi: 10.1016/j.conbuildmat.2018.11.111.

[30] C. Selvamony, M. S. Ravikumar, S. U. Kannan, and S. B. Gnanappa, "INVESTIGATIONS ON SELF-COMPACTED SELF-CURING CONCRETE USING LIMESTONE POWDER AND CLINKERS," ARPN J. Eng. Appl. Sci., vol. 5, no. 3, pp. $1-6,2010$

[31] J. Zhang, X. An, and P. Li, "Research on a mix design method of self-compacting concrete based on a paste rheological threshold theory and a powder equivalence model," Constr. Build. Mater., vol. 233, p. 117292, 2020.

[32] B. Beeralingegowda and V. D. Gundakalle, "The Effect of Addition of Limestone Powder on The Properties of Self-compacting Concrete," Int. J. Innov. Res. Sci. Eng. Technol., vol. 2, no. 9, pp. 1-8, 2013.

[33] S. Grzeszczyk and P. Podkowa, "The Effect of Limestone Filler on the Properties of Self Compacting Concrete," Annu. Trans. Nord. Rheol. Soc., vol. 17, pp. 1-7, 2009.

[34] G. Sua-iam and N. Makul, "Utilization of limestone powder to improve the properties of self-compacting concrete incorporating high volumes of untreated rice husk ash as fine aggregate," Constr. Build. Mater., vol. 38, pp. 455-464, 2013, doi: 10.1016/j.conbuildmat.2012.08.016.

[35] A. Bradu and N. Florea, "WORKABILITY AND COMPRESSIVE STRENGTH OF SELF COMPACTING CONCRETE CONTAINING DIFFERENT," Bull. Transilv. Univ. Braşov, vol. 8, no. 1, pp. 15-20, 2015.

[36] W. E. Elemam, A. H. Abdelraheem, M. G. Mahdy, and A. M. Tahwia, "Optimizing fresh properties and compressive strength of self- consolidating concrete," Constr. Build. Mater., vol. 249, p. 118781, 2020, doi: 10.1016/j.conbuildmat.2020.118781.

[37] D. Jiang et al., "Utilization of limestone powder and fly ash in blended cement: Rheology, strength and hydration characteristics," Constr. Build. Mater. Build. Mater., vol. 232, p. 117228,2020

[38] L. Shen, Q. Li, W. Ge, and S. Xu, "The mechanical property and frost resistance of roller compacted concrete by mixing silica fume and limestone powder: Experimental study," Constr. Build. Mater., vol. 239, p. 117882, 2020, doi: 10.1016/j.conbuildmat.2019.117882.
[39] K. Turk and S. Demirhan, "Effect of limestone powder on the rheological , mechanical and durability properties of ECC," Eur. J. Environ. Civ. Eng., vol. 21, no. July, pp. 1151-1170, 2017, doi: 10.1080/19648189.2016.1150902.

[40] W. Zhu and J. C. Gibbs, "Use of different limestone and chalk powders in self-compacting concrete," Cem. Concr. Res., vol. 35, no. July 2004, pp. 1457-1462, 2005, doi: 10.1016/j.cemconres.2004.07.001

[41] Y. Kim, R. Van Leeuwen, B. Cho, and V. Sriraman, "Evaluation of the Efficiency of Limestone Powder in Concrete and the Effects on the Environment," Sustainability, vol. 10, p. 550, 2018, doi: 10.3390/su10020550.

[42] Z. Wei, L. I. Liang, L. I. U. Shu-hua, V. T. N. Dao, and L. I. U. Xing-hong, "Hydration properties and thermal analysis of cement-based materials containing limestone powder," J. Cent. South Univ., vol. 24, pp. 2932-2939, 2017.

[43] M. K. M. Al-ani, A. Dawson, M. Khashaa, A. Robert, and N. Howard, "Production, microstructure and hydration of sustainable self-compacting concrete with different types of filler Production, microstructure and hydration of sustainable self-compacting concrete with different types of filler," Constr. Build. Mater., vol. 49, no. November 2018, pp. 84-92, 2013, doi: 10.1016/j.conbuildmat.2013.07.107.

[44] S. H. Liu and L. Wang, "Influence of limestone powder on hydration properties of complex binders," Mater. Res. Innov., vol. 18, pp. 186-190, 2019, doi: 10.1179/1432891714Z.000000000624

[45] M. Wu, Y. Zhang, Y. Ji, W. She, L. Yang, and G. Liu, "A comparable study on the deterioration of limestone powder blended cement under sodium sulfate and magnesium sulfate attack at a low temperature," Constr. Build. Mater., vol. 243, p. $118279,2020$.

[46] L. Chong, C. Shi, J. Yang, and H. Jia, "Effect of limestone powder on the water stability of magnesium phosphate cement-based materials," Constr. Build. Mater., vol. 148, no. September, pp. 590-598, 2017, doi: 10.1016/j.conbuildmat.2017.04.207.

[47] E. F. Irassar, V. L. Bonavetti, and M. Gonza, "Microstructural study of sulfate attack on ordinary and limestone Portland cements at ambient temperature," Cem. Concr. Res., vol. 33, pp. 31-41, 2003.

[48] E. F. Irassar, "Sulfate attack on cementitious materials containing limestone fi ller - A review," Cem. Concr. Res., vol. 39, no. 3, pp. 241-254, 2009, doi 10.1016/j.cemconres.2008.11.007

[49] C. Shi, Z. Wu, K. Lv, and L. Wu, "A review on mixture design methods for self-compacting concrete," Constr. Build. Mater., vol. 84, pp. 387-398, 2015, doi: 10.1016/j.conbuildmat.2015.03.079.

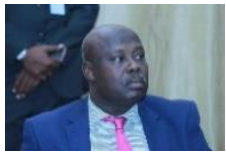

Dr Yousif Hummaida Ahmed (PhD, DIC, BSc) $\mathrm{PhD}$. in Engineering from

Imperial College/ University of London (1996) Awarded Dr Shawki Saad Scholarship. Specilization Concrete durability \& hazardous waste management technologies. Formr Head of Civil Engineering Department, Faculty of Engineering, University Of Khartoum, Sudan. Currently Chairman of the Governmental Council for registering and classifying Engineering works Contractors.

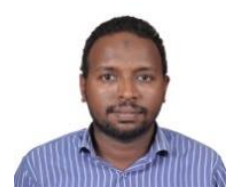

Eng. Khalid Salah Eldin Babikir (BSc, MSc) is a $\mathrm{PhD}$ student at University of Khartoum. He received a bachelor's degree in Civil Engineering from Omdurman Islamic University and a master's degree in Structural Engineering from University of Khartoum in Khartoum, Sudan. He is interested in self compacting concrtete researches. Currently works for Ouf ready mixed concrete as a quality control Engineer in Karary-Omdurman. 